\title{
XANTHOPARMELIA MOUGEOTII (PARMELIACEAE, LICHENISED ASCOMYCETES) NEW TO THE LICHEN FLORA OF HUNGARY
}

\author{
Gábor MATUS ${ }^{1 *}$, János SZEPESI ${ }^{2}$, Péter RóZSA ${ }^{3}$, László LŐ KÖ ${ }^{4}$, \\ Nóra VARGA ${ }^{5}$ and Edit FARKAS ${ }^{5}$ \\ ${ }^{1}$ Department of Botany, Institute of Biology and Ecology, Faculty of Science and Technology, \\ University of Debrecen, H-4032 Debrecen,Egyetem tér 1, Hungary; *matus.gabor@science.unideb.hu \\ ${ }^{2}$ Volcanology Research Group, Eötvös Loránd University-Hungarian Academy of Sciences, \\ H-1117 Budapest, Pázmány Péter sétány 1/C, Hungary \\ ${ }^{3}$ Department of Mineralogy and Geology, Institute of Earth Sciences, Faculty of Science and \\ Technology, Debrecen University, H-4032 Debrecen, Egyetem tér 1, Hungary \\ ${ }^{4}$ Hungarian Natural History Museum, H-1431 Budapest, Pf. 137, Hungary \\ ${ }^{5}$ Institute of Ecology and Botany, MTA Centre for Ecological Research, \\ Hungarian Academy of Sciences, H-2163 Vácrátót, Alkotmány u. 2-4, Hungary
}

Matus, G., Szepesi, J., Rózsa, P., Lőkös, L., Varga, N. \& Farkas, E. (2017): Xanthoparmelia mougeotii (Parmeliaceae, lichenised Ascomycetes) new to the lichen flora of Hungary. - Studia bot. hung. 48(1): 89-104.

\begin{abstract}
Xanthoparmelia mougeotii is a usnic acid containing, small foliose, sorediate, parmelioid lichen species with a pantemperate distribution. In Europe it occurs in most countries especially in cool, humid, "suboceanic" habitats, mainly on acidic rocks, and rather sporadic in the continental areas, e.g. isolated populations in Slovakia (near Strečno) or in Ukraine (Crimea). Recently another isolated Central European population was discovered in the Zemplén Mts (NE Hungary), approx. $200 \mathrm{~km}$ far from the Slovak population.
\end{abstract}

Key words: Hungary, lichen-forming fungi, lichenicolous fungi, Xanthoparmelia

\section{INTRODUCTION}

Intensified field work and application of new techniques resulted in several new taxonomic and chorological findings in the macrolichen genus Xanthoparmelia worldwide (e.g. Crespo et al. 2010, Giordani et al. 2002, HALE 1974, 1990, HAWKsworth et al. 2008, 2011, KANigowsKi et al. 2016) and also in Hungary (FARKAs et al. 2012, 2015, MATUs et al. 2015, MoLNÁR et al. 2012). The species-rich genus counts ca 14 usnic acid containing species in the Carpathian Basin and nearby areas, i.e. AT: 4; CZ: 7, DE: 7, HR: 4, HU: 7; RO: 2, RS: 4, SI: 2, SK: 9, UA: 7 (Bielczy et al. 2004, Ciurchea 2004, Guttová et al. 2013, HAFELLNER and TÜRK 2001, KONDRATYUK et al. 1998, LišKA et al. 
2008, LÖ KÖS and FARKAS 2009, ORTHOVÁ-SLEZÁKOVÁ 2004, SAVIĆ and TIBELL 2006, Suppan et al. 2000, TÜRK and HAFELlner 2010, Wirth et al. 2013).

The sub-Atlantic species, Xanthoparmelia mougeotii, is reported in decreasing frequencies in a NW-SE European gradient (climatically from oceanic to continental). Up to now a single locality of this species has been reported from Slovakia representing the only known habitat within the Carpathian Basin.

This paper gives an account on the discovery of the species in Hungary including the geological conditions of the new habitat. We provide data on population size of this new member of the Hungarian lichen flora and report on accompanying cryptogamic, as well as vascular species. Significance of the new discovery is discussed in a European context with special regard to substrate preference, altitude selection, and conservational status.

\section{MATERIAL AND METHODS}

Voucher specimens are deposited in BP (Hungarian Natural History Museum, Budapest, Hungary), DE (Soó Rezső Herbarium, Debrecen University, Debrecen, Hungary) and EGR (Eszterházy Károly University of Applied Sciences, Eger, Hungary). Herbarium acronyms follow the Index Herbariorum online (Thiers 2016). Hafellner and Calatayud (1999), Ihlen and Wedin (2008), Smith et al. (2009), and Wirth et al. (2013) were used for identifications. Morphological-anatomical investigations and $\mathrm{KOH}$ spot test were carried out by standard methods (ORANGE et al. 2010) using Olympus SZX-7 binocular dissecting microscope and Olympus CX-41 stereo microscope. HPTLC analysis for chemical substances was applied in solvent system $\mathrm{C}$ according to ARUP et al. (1993). The distribution map of Xanthoparmelia mougeotii was prepared by the computer program for geographical information system, Quantum GIS (QGIS 2.18 Las Palmas, 2016) based on the Central European grid system of $5 \mathrm{~km} \times 6$ km units (BORHIDi 1984, Ni KLFELD 1971).

\section{The studied species}

Xanthoparmelia mougeotii (Schaer.) Hale

(Parmelia mougeotii Schaer.)

(Fig. 1)

Thallus small foliose, $2-4 \mathrm{~cm}$ in diam., tightly adnate to substrate, centrally may also be areolate; lobes shiny, green-grey, yellow-grey, yellow-green or partially brownish, smooth to rugulose or cracked, narrow, ca $0.2-0.5 \mathrm{~mm}$ wide, sublinear, flattened or somewhat convex, radiating, separate and contiguous to 
subimbricate, lobe ends subtruncate, brown rimmed, smooth to crenate, eciliate; medulla white; lower surface and rhizines dark brown to black, rhizines simple, 0.1-0.2 mm long. Soredia farinose, orbicular, hemispherical to subglobose, yellow to grey-yellow. Apothecia and pycnidia not seen in Hungarian material.

Chemistry: upper cortex $\mathrm{K}+$ yellow to orange, $\mathrm{C}-, \mathrm{KC}-, \mathrm{P}+$ orange, $\mathrm{UV}-$; medulla $\mathrm{K}+$ yellow becoming dark red, $\mathrm{C}-, \mathrm{KC}-, \mathrm{P}+$ orange (usnic acid, stictic acid complex, norstictic acid).

Substrate and ecology: mainly on siliceous rocks often in open, exposed habitats, with a pantemperate to subarctic distribution in Europe (Fig. 2), Asia, southern Africa, and western North America.

\section{RESULTS AND DISCUSSION}

The first specimens of a small, sorediate, parmelioid lichen have been collected on rock outcrops of Mt Fövenyes-tető ( $503 \mathrm{~m}$; $48.46667^{\circ} \mathrm{N}, 21.40500^{\circ} \mathrm{E}$; grid unit identifier: 7594.1), 4 km SE of Telkibánya, Zemplén Mts, NE Hungary in June 2015 (Fig. 3). Morphological features pointed to a limited set of species including two species still unreported from the country. Results of the usual morphological investigations and spot tests $(\mathrm{K}+$ yellow, $\mathrm{C}-, \mathrm{P}+$ orange) and TLC (presence of usnic acid, stictic acid complex, as well as of norstictic acid) excluded the morphologically similar Arctoparmelia incurva and Parmeliopsis ambigua, therefore the new finding has been identified as Xanthoparmelia mougeotii (Schaer.) Hale, which was unknown from Hungary (Lökös and FARKAS 2009, VERSEGHY 1994). Voucher specimens have been deposited in the Soó Herbarium of the University of Debrecen (DE), in the Eszterházy Károly University of Applied Sciences, Eger (EGR) and in the Hungarian Natural History Museum, Budapest (BP), as follows.

Hungary. Borsod-Abaúj-Zemplén megye, Telkibánya, Mt Fövenyes-tető. Lat.: 48 28’ 00.0” N; Long.: 2124' 17.7” E; Alt.: 498 m a.s.l. Coll.: Matus, G., Takács, A., 06.06.2015 [DE 1493, EGR 6596, BP].

Hungary. Borsod-Abaúj-Zemplén County, Zemplén Mts, Telkibánya, Mt Fövenyes-tetö, on siliceous rock (rhyolite). Lat.: 48 $28^{\prime} 00.2^{\prime \prime} \mathrm{N}$; Long.: $21^{\circ} 24^{\prime}$ 17.5” E; Alt.: $500 \mathrm{~m}$ a.s.l. Coll.: Lőkös, L., Matus, G. and Varga, N., 08.08.2015 [BP, together with Lichenostigma cosmopolites].

\section{Population size of Xanthoparmelia mougeotii in Hungary}

A mapping survey carried out in August 2015 outlined a population area of ca $50 \times 20 \mathrm{~m}$ between altitudes of $475-500 \mathrm{~m}$ in Mt Fövenyes-tető. The population occupies the upper part of the SW to SSE facing slopes around the summit. 

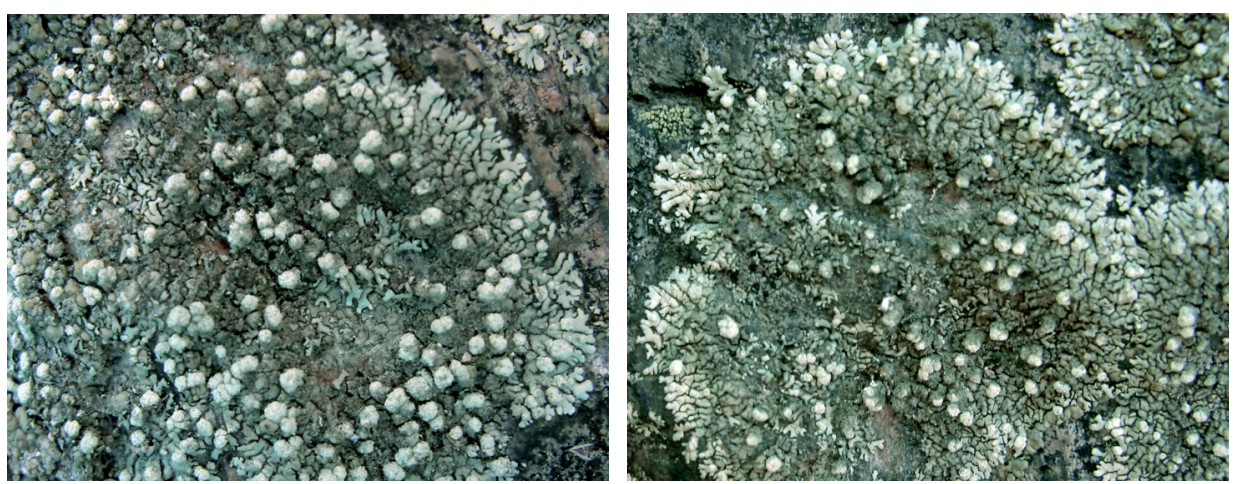

Fig. 1. Xanthoparmelia mougeotii at Mt Fövenyes-tető (Zemplén Mts, NE Hungary).

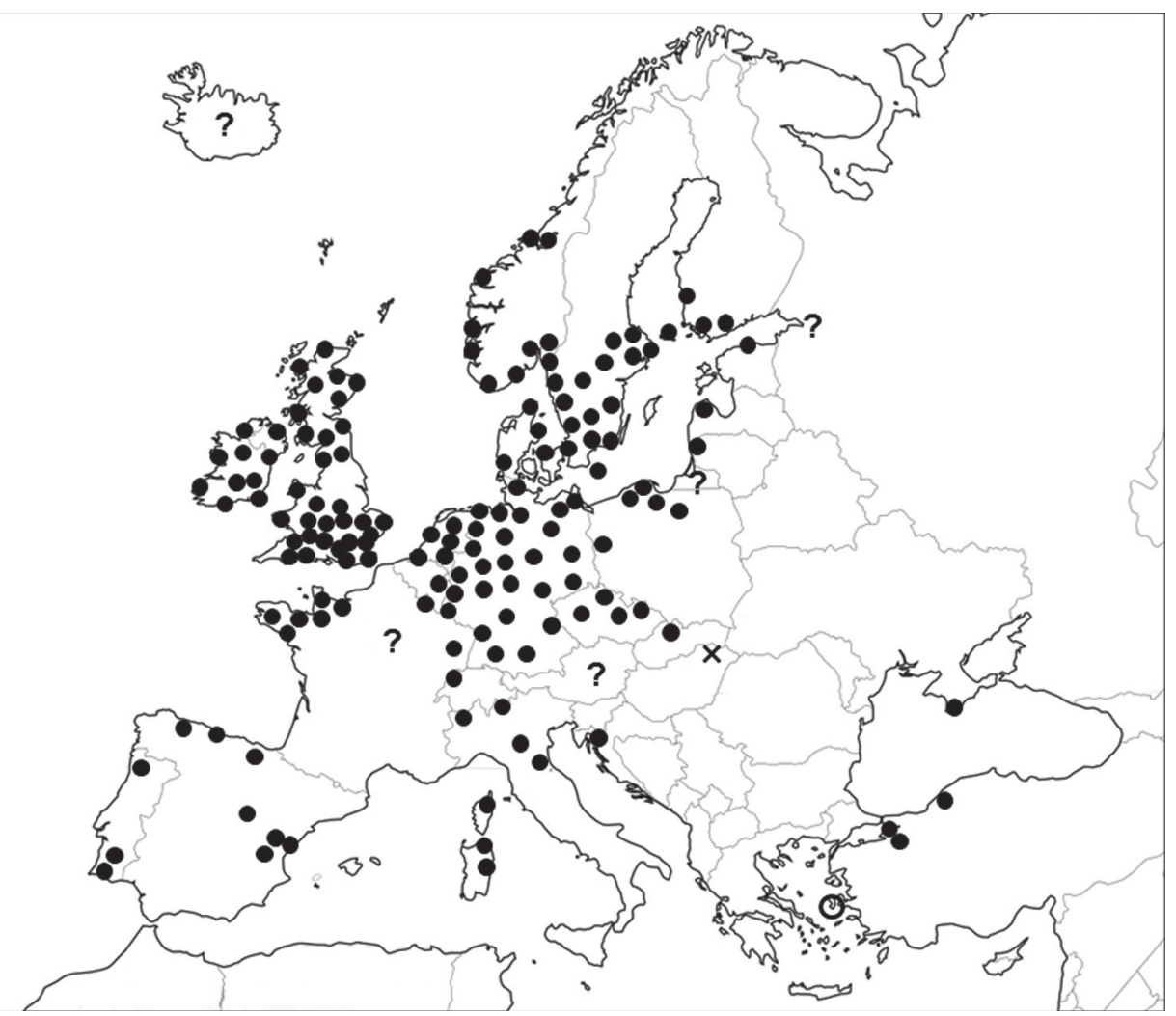

Fig. 2. European distribution of Xanthoparmelia mougeotii. $\bullet$ (filled circle) $=$ confirmed occurrence, $\circ$ (empty circle $)=$ doubtful record, $\times($ cross $)=$ new occurrence. 
It is concentrated on exposed or half-shaded larger rock outcrops on the SSW slope, but becomes more scattered towards the S and SSE slopes, where only scattered exposed outcrops emerge from the moving scree field. Thalli mostly occupy smooth rock surfaces, vertical as well as leaning ones, but are also present on some more weathered, fractured rocks. Estimation of population size resulted in a few times ten of mature, sorediate thalli and a few hundred young, non-sorediate thalli of various size. Fertile specimens were not noticed.

\section{Vegetation of the habitat and accompanying species}

Very seldom it can also grow on other substrata like acidic bark (on Betula or Populus in Europe, or on Hebe elliptica, a Plantaginaceae shrub at the Falkland Islands). Wooden structures as well as other artificial substrates in synanthropic surroundings (metal, glass, plastic or rubber) make rare exceptions. In figures, nearly $99 \%$ of the Dutch records is epilithic (over $73 \%$ on granite, $15 \%$ on basalt and $10 \%$ on brick (with acidic chemistry), http://www.verspreidingsatlas.nl).

An analogous explanation on this geographical pattern, originally applied for weedy vasculars (HolzNER 1978), can be postulated. Acidophytes showing good competitive abilities and capable of tolerating high nutrient loads under preferred climatic conditions can turn into weak competitors and are confined to extremely acidic, low-nutrient habitats at the edge of their climatic tolerance.

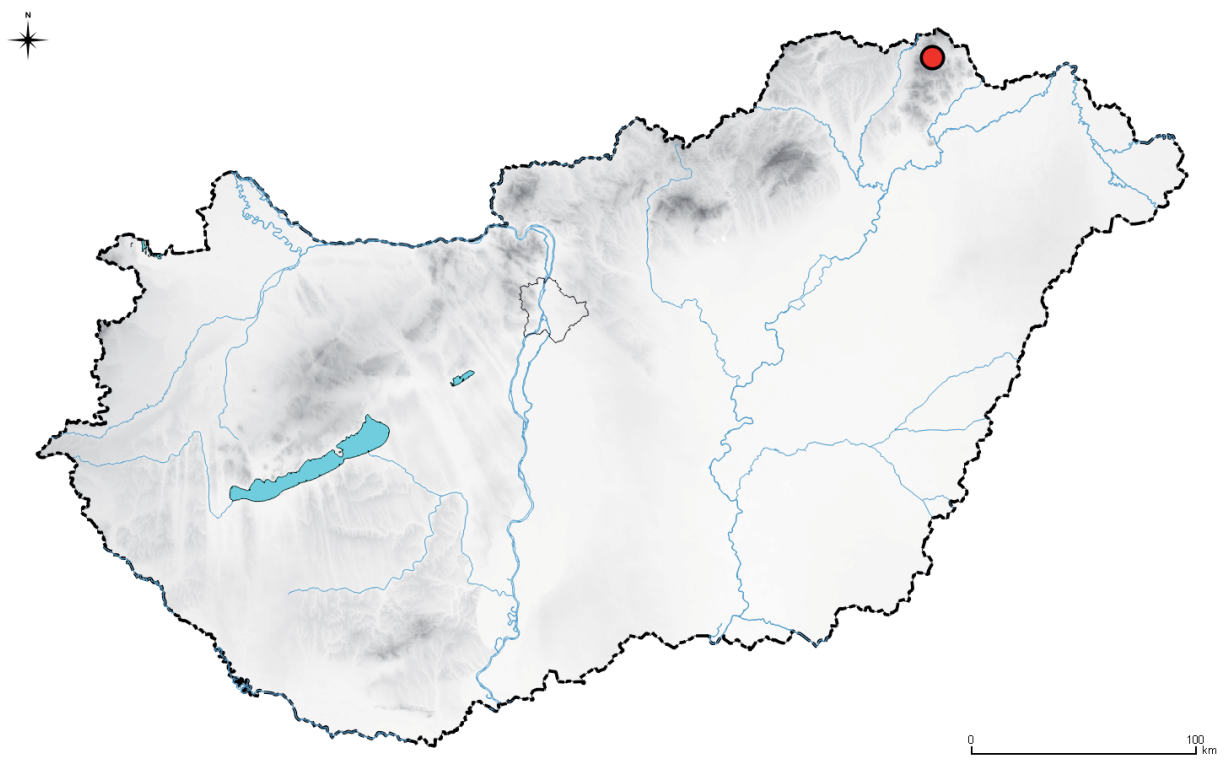

Fig. 3. The Hungarian locality of Xanthoparmelia mougeotii. 
Vegetation of the Hungarian site (Fig. 4) is a sparse acidic forest with Fagus sylvatica, Quercus petraea, and Betula pendula in the canopy intermingled with barren moving scree fields. The sporadic herb layer consists of the acidophytes Festuca ovina, Genista pilosa, Luzula luzuloides, Rumex acetosella, and Vaccinium myrtillus. Accompanying cryptogams include saxicolous and some terricolous lichen species: Acarospora fuscata, Cladonia mitis, C. squamosa, C. uncialis, Lecidea fuscoatra, Porina chlorotica (= Pseudosagedia ch.), Pycnothelia papillaria, Rhizocarpon geographicum, Vulpicida pinastri, Xanthoparmelia conspersa, X. protomatrae, and $X$. verruculifera. Several thalli of Xanthoparmelia mougeotii are heavily covered by the lichenicolous microfungi Lichenostigma cosmopolites, similarly to the thalli of the accompanying $X$. conspersa and $X$. protomatrae. Presence of the mosses Bartramia pomiformis and Grimmia muehlenbeckii (ERZBERGER 2009) occurring sporadically on acidic volcanic outcrops, as well as of Leucobryum glaucum in more shaded habitats has been proved.

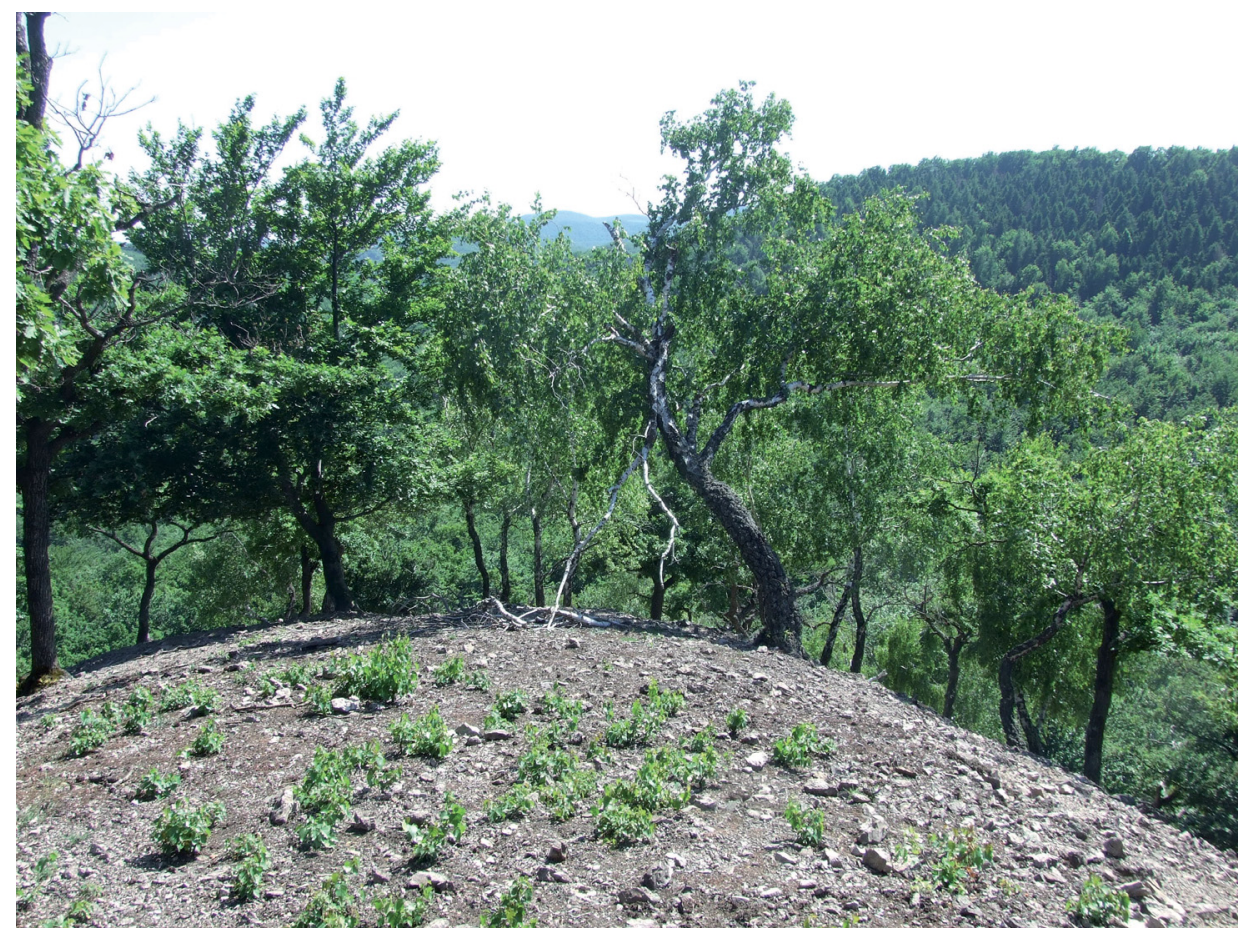

Fig. 4. Open, rocky habitat of Xanthoparmelia mougeotii at Mt Fövenyes-tető. 


\section{Distribution}

Xanthoparmelia mougeotii with a dominantly pantemperate distribution has mostly been recorded at cool and humid regions of North, Central and South America, South Africa, New Zealand, as well as Hawaii and has some scattered data from the Far East (Japan). Subtropical and tropical records from Brazil, Colombia, Ecuador, Peru, Uruguay, and Venezuela are from higher altitudes characterised by similar climates. This holds for the only record from the Middle East (Asir province in SW of Saudi Arabia with monsoon and over $2000 \mathrm{~m}$ of elevation).

Like in other continents, most European records originate from regions under the influence of oceanic climate (KLEMENT 1958). Most data have been gathered from the UK, where the species is probably the most widespread. Further countries with higher frequencies are Ireland, the Netherlands and certain parts of Belgium, France, Germany, Spain, and Portugal (BEguinot 1981, Cezanne and Eichler 1991, Klement 1958, LAmbinon 1966, LAmbinon and Sérusiaux 1985, Stordeur et al. 2015, VAN DEN BroeCK et al. 2008). In the Scandinavian countries it is the most abundant in the seaside provinces (Høiland 1973, Reve 1981, SANTESSON et al. 2004) and, with significantly lower number of total records, the same holds for Poland (FA£TYNowicz 2003, KuKWA 2005, KuKWA and ZduńCZyk 2011), Latvia (Abolina et al. 2015, Piterāns 1996), and Estonia (RAndlane and SAAg 1999). Recent discoveries from Ukraine and Turkey refer to the Crimean Peninsula (KHodosovtsev 2013) and the Black Sea-Marmara Sea region (ÇoBAnoĞLU ÖzyıĞıtoĞLU and Yavuz 2015, Halici and Cansaran-Duman 2007), respectively. Data from landlocked countries are rather scarce. A dozen of records is assigned to the Czech Republic from the 1930s to the 1960s (LišKA et al. 2008, MüLLER 1949, Suza 1949), whereas Slovakia has a recently rediscovered single locality (OrThová 2003, Suza 1934).

Only old records of Xanthoparmelia mougeotii are available from Switzerland (Jura Mts; ClerC and Truong 2012, MAgnin 1906), whereas none from Austria (HAFELLNER and TürK 2001, TüRK and HAFELLNER 2010), Romania (CIURCHEA 2004), Serbia (SAvić and Tibell 2006), and Slovenia (Suppan et al. 2000).

WIRTH et al. (2013) characterised the European distribution of Xanthoparmelia mougeotii as wide as the southern boreal-temperate-sub-Atlantic-Mediterranean (montane) species.

The new locality forms the first record of the species in Hungary, as well as the second occurrence within the Carpathian Basin. As such it is a highly isolated occurrence, which lies over $200 \mathrm{~km}$ to the closest known one in Strečno, Slovakia and between 350 to $550 \mathrm{~km}$ far from occurrences in the Czech Republic 
(Orthová 2003, Suza 1934, GBIF query). Distance of the new site from the Baltic and Adriatic Sea is ca 630 and $670 \mathrm{~km}$, respectively. These figures are about $100 \mathrm{~km}$ more than those of the Strečno site, suggesting an even more continental position. The recent Crimean and Turkish occurrences are $c a 1100 \mathrm{~km}$ from the Hungarian locality.

\section{Climate}

Mean annual temperature of the region is $c a 8^{\circ} \mathrm{C}\left(<-4^{\circ} \mathrm{C}\right.$ in January, $<19$ ${ }^{\circ} \mathrm{C}$ in July) with $>100$ frosty days. Mean annual precipitation is over $700 \mathrm{~mm}$ (probably over $750 \mathrm{~mm}$, but due to the lack of measuring infrastructure the data is uncertain) with a midsummer maximum (HAVASSY and NÉMETH 2007).

In England, forming the European climatic optimum of Xanthoparmelia mougeotii, the species is abundant in urban habitats, such as churchyards.

\section{Geology, substrate preference and chemistry}

The species is dominantly saxicolous, mostly occupying base-poor stones. Preferred ones are smooth, usually vertical or steep surfaces of acidic (rarely basic), volcanic and metamorphic rocks, such as granite, schist, shales, quartz(ite), porphyry, rhyolite, sandstone and basalt. (Older collections have often been labelled with the term "igneous rock"). Primary habitats are typically scree fields, rock outcrops, cliffs, boulders, stones, pebbles or siliceous conglomerates. In lack of substrate naming often the geographical name itself implies epilithic occurrence (e.g. "tor", which is equivalent for steep craggy hill or "crag" meaning steep rugged rock or cliff). Secondary habitats include disused quarries, mines or slate debris.

In NW Europe records from anthropogenic surroundings greatly outnumber natural ones, partly because of their easy accessibility compared to natural ones. Highest portion of these are the churchyard (graveyard, cemetery) records (2240), which make up over $50 \%$ of GBIF records from GB, a result of the Lowland Churchyard project of the British Lichen Society, but also close to 20\% in Sweden. Except for tombstones often other stone or slate structures or buildings can provide habitats. These include churches (167), bridges (90), houses (27), chapels (24), farms (21), walls (18), prehistoric monuments (10, e.g. stone circles of Stonehenge or the dolmens of Friesland or Sweden), fences, slated roofs, even a cathedral and a lighthouse.

Due to old mining traditions, geology of the Telkibánya district has been thoroughly studied (Hermann 1952, Il Keyné Perlaki 1972, Kozák 1994, Liffa 1953, Richthofen 1861, SzÉKYNÉ Fux 1970). Recently detailed palaeovolcanic reconstruction has been completed (SzEPESI 2009, SZEPESI and KozÁK 2008). 
The studied region (incl. also Mt Fövenyes-tető and its surroundings), referred to as "Northern Rhyolite District" (SzÁDECZKY 1887), forms an about 35 $\mathrm{km}^{2}$ sized area in the northern Hungarian section of the mountain range TokajSlanské Vrchy Mountains (Tokaj-Szalánci-hegység), which is especially and uniquely rich in siliceous lavas.

The substrate of Xanthoparmelia mougeotii identified as highly acidic, coherent rhyolite predominantly shows grey-veined, flow-banded pattern representing core region of lava domes and flows of Sarmatian Stage (Middle-Late Miocene, 13-11 Myr) (SzEPESI et al. 2016). The erosional forms show very steep sided morphology (Cser-hegy, Kis-Ork-hegy, Nagy-Ork-hegy, Ó-Gönc) with dense periglacial debris ( $\mathrm{dm}$ sized) and boulders.

Chemical composition of the substrate at the Telkibánya site (Table 1) is similar to the Strečno one as rhyolite forms the surface equivalent of the plutonic granite. A common similarity is the high proportion of silica (over $77 \%$ of $\mathrm{SiO}_{2}$ ), resulting in very low surface $\mathrm{pH}$ values.

Table 1. Chemical composition of the substrate rock of Xanthoparmelia mougeotii at Mt Fövenyes-tető (Zemplén Mts, NE Hungary).

\begin{tabular}{cc}
\hline Szepesi et al. (unpubl.) & mean (range) $\%(\mathrm{n}=4)$ \\
\hline $\mathrm{SiO}_{2}$ & $77.35(77.29-77.53)$ \\
$\mathrm{Al}_{2} \mathrm{O}_{3}$ & $12.67(12.60-12.80)$ \\
$\mathrm{K}_{2} \mathrm{O}$ & $4.30(4.18-4.44)$ \\
$\mathrm{Na}_{2} \mathrm{O}$ & $3.57(3.48-3.74)$ \\
$\mathrm{Fe}_{2} \mathrm{O}_{3}$ & $1.31(1.07-1.46)$ \\
$\mathrm{CaO}$ & $0.72(0.68-0.77)$ \\
\hline
\end{tabular}

Altitude preference

Distance of the new site from the closest sea is about $100 \mathrm{~km}$ more from the Adriatic Sea and about $200 \mathrm{~km}$ more from the North Sea, than that of the Strečno site. Macroclimate data also underline the peculiarity of this landlocked location. Forming the most continental site in Europe, it does not seem to make a favourable habitat. The region numbers over 100 frosty days, while midsummer drought is common.

In Fennoscandia, where acidic substrates are widespread, climate seems to limit vertical distribution. For example altitude records vary from 2 to $155 \mathrm{~m}$ in Norway ( $\mathrm{n}=95$; http://www.nhm2.uio.no) and 1 to $90 \mathrm{~m}$ in Sweden ( $\mathrm{n}=197$; GBIF query). We know little about occurrences in the Mediterranean region, but the available data suggest a preference of intermediate heights. In Spain, for example, altitude of the 15 GBIF records varies between 870 and $1600 \mathrm{~m}$. 
Higher precipitation due to higher altitude may compensate air humidity at least in periods when thalli are active. Worldwide distribution data suggest that higher altitude and humid climate can support the species also out of the temperate zone. Records from (sub)tropics are confined to higher altitudes and, at least seasonally, to humid climate. This holds for South American records of the Andes (Peru, Colombia, and Venezuela at 3200 to $4100 \mathrm{~m}$ ) and for the monsooninfluenced "wet corner" at SW Saudi Arabia (up to 3100 m, Abha, Asir Province, GBIF ID: 1030428941).

All Central European elevation data fall in the same range. Altitudes of our record ( 475 to $500 \mathrm{~m}$ ) are very similar to ones in the Czech Republic (464 \pm 173 m; 260 to $765 \mathrm{~m} ; \mathrm{n}=17$ ), as well as to the Slovakian collections (380 to $425 \mathrm{~m}$ ). These figures are somewhat higher than those from NW Europe or Fennoscandia and the Baltic countries.

Survey for other potential habitats for more populations

Some of the nearby rock outcrops with the presence of fluidal rhyolite (e.g. Tér-hegy, Kis-Tér-hegy, Halyagos-tető, Csoszota-tető) have partly or fully been forested with Picea abies or Pinus sylvestris in the 1960s, therefore a number of potential habitats has been eliminated. Survey of non-forested neighbouring outcrops with similar geology (i.e. Kis-Ork-hegy, Nagy-Ork-hegy, Solymos, Ó-Gönc) in 2015 and 2016 yielded no further records of the species.

\section{Conservational status}

The species is common in parts of NW Europe under oceanic influence and with abundant acidic substrata. No data on possible vulnerability emerged from Great Britain (> 3800), Belgium ( $>30$ ), Ireland ( $>70)$, Atlantic part of France $(>20)$, Luxembourg (>10), Norway (>100) or Sweden (> 500). In Denmark ( 10) and the Netherlands $(\sim 40)$ it is already rare, but conservational status is of "least concern" (SøснтING and AlstRup 2008, http://bios.au.dk) or not threatened yet (bttp://www. verspreidingsatlas.nl), respectively. Little is known about the conservational status in the Mediterranean. The species seems to be less widespread as suggested by $>35$ records from Spain. In Italy its status is labelled from rare to extremely rare in the few provinces where present (bttp://dbiodbs.univ.trieste.it). (Number of GBIF and http://www.lichenology.info records are given in brackets).

Further from the seas it becomes more threatened, which is reflected in legal handling. In Germany, being present in $<50$ floristical grid cells, it is considered as very rare and vulnerable in recent evaluation (WIRTH et al. 2011, http://www. flechten-deutschland.de). 
In Poland it is considered as vulnerable (CIEŚLIŃs KI et al. 2003, 2006) and the same holds for the Baltic countries (endangered in Latvia, PItERĀNs 1996, http://latvijas.daba.lv; threatened in Lithuania, Motiejūnaité 2002; endangered in Estonia, Trass 1958, RANDLANE et al. 2008, http://www.ut.ee) and least concern in Finland (STENROOS et al. 2016), where considered as endangered. Further along the NW to SE continentality gradient, $X$. mougeotii is endangered in the Czech Republic (LIŠKA et al. 2008). Recent status of the species in Slovakia can be considered as "critically endangered" (GutTová et al. 2013). Rediscovery of an apparently very small population (Strečno, Malá Fátra Mts; OrTHové 2003) proved its presence in the Carpathian Basin after already believed extinct for decades (1922: Suza 1934, Pišút 1993, Pišút et al. 1993, 1998, 2001). Since 2004 it is legally protected (in category 2) in Estonia (RANDLANE et al. 2008).

The new Hungarian site forms a Natura 2000 area and part of the Zemplén Protected Landscape area. Intensive erosion, caused by a significant population of the introduced moufflon, may pose a threat to the site. Thin rocky soils are badly eroded and vascular vegetation greatly damaged, resulting in the possible loss of the legally protected Vaccinium vitis-idaea (HULJÁK 1997), though this effect did apparently not influence much the outcrops.

As a species of oceanic character $\left(\mathrm{K}_{\text {Wirth }}=2\right)$ (WIRTH 2001, 2010) it forms a unique member of this kind in the lichen flora of the Carpathian Basin. Up to now the presence of only $16 \mathrm{~K}_{\text {Wirth }}=2$ species ( $<2 \%$ of the lichen flora) has been proved in the continental Hungary. Taking these circumstances into consideration Xanthoparmelia mougeotii is worth for legal protection also in Hungary. Being rare with only one locality in Hungary it is also suggested as critically endangered species in the Hungarian lichen red list, until we have more information about its population dynamics and its detailed distribution.

Acknowledgements - The authors are grateful for Zs. Bereczki, R. Balogh, A. Takács, and Z. Varga for their help during field surveys. Identification of mosses collected from the site has been accomplished by P. Erzberger and Cs. Németh. Friendly logistic support in Telkibánya has been provided by P. Hulják, I. Rimán (Telkibánya Forestry) and B. Bereczky (ÖKOdemo).

Összefoglaló: A Xanthoparmelia mougeotii mérsékelt övi, illetve trópusi magashegységi elterjedésü, uzneasav-tartalmú, kis termetü, szorédiumos, parmelioid lombos zuzmófaj. Európa legtöbb országában honos, súlypontosan a hüvös, nedves klímájú "szubóceánikus" területeken, zömmel savanyú kémhatású kőzeteken. Kontinentális területeken szórványos, izolált előfordulású, a Kárpát-medencében eddig csak egyetlen populációja volt ismert (Sztrecsnó, Kis-Fátra, Szlovákia). A közelmúltban egy további, izolált közép-európai előfordulásra derült fény a Zempléni-hegységben (Tokaj-Szalánci-hegység), a szlovákiai populációtól mintegy 200 km-re. 


\section{REFERENCES}

Abolina, A., Piterāns, A. and Bambe, B. (2015): Lichens and bryophytes in Latvia: checklist. Daugavpils Univ. Akad. apg. "Saule”; Latvijas Valsts mež. inst. "Silava”, Latvia, 213 pp.

Arup, U., Ekman, S., Lindblom, L. and Mattsson, J.-E. (1993): High performance thin layer chromatography (HPTLC), an improved technique for screening lichen substances. Lichenologist 25(1): 61-71. https://doi.org/10.1017/s0024282993000076

Beguinot, J. (1981): Extension, dans l'Autunois, de deux especes a affinités subatlantiques: Graphis elegans et Parmelia mougeotii. - Bull. Soc. Hist. Nat. Creusot 38: 20-21.

Bielczy K, U., Lackovičová, A., FARKAs, E. E., LöKös, L., LišKa, J., Breuss, O. and KondRATYUK, S. Y. (2004): Checklist of lichens of the Western Carpathians. - W. Szafer Institute of Botany, Polish Academy of Sciences, Kraków, 181 pp.

BorHIDI, A. (1984): Role of mapping the flora of Europe in nature conservation. - Norrlinia 2: 87-98.

Cezanne, R. and Eichler, M. (1991): Parmelia mougeotii Schaerer ex Dietr. im badischen Odenwald. - Carolinea 49: 121-122.

Cieślińs ki, S., Czyżewska, K. and Fabiszewski, J. (2003): Red list of extinct and threatened lichens in Poland. - Monogr. Bot. 91: 13-49.

Cieśliński, S., Czyżewska, K. and Fabiszewski, J. (2006): Red list of the lichens in Poland. - In: MireK, Z., ZARZYCKi, K., Wojewoda, W. and SzelĄG, Z. (eds): Red list of plants and fungi in Poland. W. Szafer Institute of Botany, Polish Academy of Sciences, Kraków, pp. 71-89.

Ciurchea, M. (2004): Determinatorul lichenilor din România. - Editura BIT, Iaşi, 488 pp.

Clerc, P. and Truong, C. (2012): Catalogue des lichens de Suisse. - http://www.ville-ge.ch/musinfo/bd/cjb/cataloguelichen

ÇовANOĞLU ÖZYıĞITOĞLU, G. and YAVUZ, M. (2015): Lichen records from two military bases in the Asian Side of Istanbul. - Studii şi comunicări, Ştiinț. Nat. 31(2): 37-46.

Crespo, A., Kauff, F., Divakar, P. K., del Prado, R., Pérez-Ortega, S., de Paz, G. A., FeRencova, Z., Blanco, O., Roca-Valiente, B., Núñez-Zapata, J., Cubas, P., Argüello, A., Elix, J. A., Esslinger, T. L., Hawksworth, D. L., Millanes, A., Molina, M. C., Wedin, M., Ahti, T., Aptroot, A., Barreno, E., Bungartz, F., Calvelo, S., Candan, M., Cole, M. J., Ertz, D., Goffinet, B., Lindblom, L., Lücking, R., Lutzoni, F., Mattsson, J.-E., Messuti, M. I., Miadlikowska, J., Piercey-Normore, M. D., Rico, V. J., Sipman, H. J. M., Schmitt, I., Spribille, T., Thell, A., Thor, G., Upreti, D. K. and LumbsCH, H. Th. (2010): Phylogenetic generic classification of parmelioid lichens (Parmeliaceae, Ascomycota) based on molecular, morphological and chemical evidence. - Taxon 59: 1735-1753.

Erzberger, P. (2009): The genera Grimmia and Coscinodon (Grimmiaceae, Musci) in Hungary. - Studia bot. hung. 40: 37-124.

Faetrynowicz, W. (2003): The lichens, lichenicolous and allied fungi of Poland - an annotated checklist. - W. Szafer Institute of Botany, Polish Academy of Sciences, Kraków, 435 pp.

FARKAS, E., LöKös, L. and MOLNÁR, K. (2012): Taxonomic revision of the usnic acid containing Xanthoparmelia species in Hungary, morphological, chemical and molecular investigations. Abstracts, IAL7 Symposium, "Lichens: from genome to ecosystems in a changing world". Bangkok, Thailand, 9-13 January, 2012, p. 107.

FArkas, E., Kursinszki, L., Szőke, É. and Molnár, K. (2015): New chemotypes of the lichens Xanthoparmelia pulvinaris and X. subdiffluens (Parmeliaceae, Ascomycota). - Herzogia 28(2): 679-689. https://doi.org/10.13158/heia.28.2.2015.979 
Giordani, P., Nicora, P., Rellini, I., Brunialti, G. and Elix, J. A. (2002): The lichen genus Xanthoparmelia (Ascomycotina, Parmeliaceae) in Italy. - Lichenologist 34(3): 189-198. https://doi.org/10.1006/lich.2002.0384

Guttová, A., LackovičovÁ, A. and Pišút, I. (2013): Revised and updated checklist of lichens of Slovakia (May 2013). - Biologia 68(5): 845-850. https://doi.org/10.2478/s11756-013-0218-y

HAFELlNER, J. and CALATAYUd, V. (1999): Lichenostigma cosmopolites, a common lichenicolous fungus on Xanthoparmelia species. - Mycotaxon 72: 107-114.

HAFellner, J. and TüRK, R. (2001): Die lichenisierten Pilze Österreichs - eine checkliste der bisher nachgewiesenen Arten mit verbreitungsangaben. - Stapfia 76: 1-167.

Hale, M. E. (1974): Bulbothrix, Parmelina, Relicina, and Xanthoparmelia, four new genera in the Parmeliaceae. - Phytologia 28: 479-490.

HALE, M. E. (1990): A synopsis of the lichen genus Xanthoparmelia (Vainio) Hale (Ascomycotina, Parmeliaceae). - Smiths. Contr. Bot. 74: 1-250. https://doi.org/10.5479/si.0081024x.74

Halici, M. G. and Cansaran-Duman, D. (2007): Lichenized and lichenicolous fungi of Yaylacik (Bolu) and Yenice (Karabük) Research Forests in Turkey. - Mycol. Balcan. 4(3): 97-103.

Havassy, A. and NÉmETH, Á. (2007): Éghajlati adottságok. (Climatic features). - In: BARÁz, Cs. and Kiss, G. (eds) (2007): A Zempléni Tájvédelmi Körzet. (Zemplén Protected Landscape Area). Bükki Nemzeti Park Igazgatóság, Eger, pp. 91-94.

Hawksworth, D. L., Divakar, P. K., Crespo, A. and Ahti, T. (2011): The checklist of parmelioid and similar lichens in Europe and some adjacent territories: additions and corrections. Lichenologist 43(6): 639-645. https://doi.org/10.1017/s0024282911000454

Hawksworth, D. L., Blanco, O., Divakar, P. K., Ahti, T. and Crespo, A. (2008): A first checklist of parmelioid and similar lichens in Europe and some adjacent territories, adopting revised generic circumscriptions and with indications of species distributions. - Lichenologist 40(1): 1-21. https://doi.org/10.1017/s0024282908007329

Hermann, M. (1952): Telkibányai riolitok és andezitek petrográfiája és petrokémiája. - Földt. Közl. 82: 349-367.

HøILAND, K. (1973): Bidrag til lavfloraen i Vest-Agder. (Contribution to the lichen flora of VestAgder, SW Norway). - Blyttia 31: 211-216.

Holzner, W. (1978): Weed species and weed communities. - Vegetatio 38(1): 13-20. https://doi.org/10.1007/bf00141295

HulJák, P. (1997): The natural habitat of cowberry (Vaccinium vitis-idaea L.) and the possibilities of its protection. - Term.véd. Közlem. 5-6: 41-53.

Ilkeyné Perlaki, E. (1972): A Tokaji-hegység harmadkori savanyú vulkanizmusa. (Silicic volcanism of the Tokaj-mountains). - OFG Data Storage, Budapest, 256 pp. (mscr.)

IHLEN, P. G. and Wedin, M. (2008): An annotated key to the lichenicolous Ascomycota (including mitosporic morphs) of Sweden. - Nova Hedwigia 86: 275-365.

Kanigowski, P., Flakus, A., Oset, M., Kowalewska, A., Rykaczewki, M. and Kukwa, M. (2016): The lichen family Parmeliaceae in Poland. Xanthoparmelia species containing usnic acid. - Herzogia 29(1): 108-119. https://doi.org/10.13158/heia.29.1.2016.108

KHodosovtsev, A. Ye. (2013): Lichen-forming and lichenicolous fungi from Aju-Dag Mt. new to Ukraine and Crimea. - Chornomors'k. Bot. Zh. 9(1): 84-88.

Klement, O. (1958): Parmelia mougeotii Schaer. im Naturschutzgebiet Romberg bei Lohr/M. und ihre Verbreitung in Europa. - Nachr. Naturwiss. Mus. Aschaffenburg 58: 39-47.

Kondratyuk, S. Y., Khodosovtsev, A. Y. and Zelenko, S. D. (1998): The second checklist of lichen-forming, lichenicolous and allied fungi of Ukraine. - M. H. Kholodny Institute of Botany, Kiev, 179 pp. 
KоzÁк, M. (1994): Telkibánya közetföldtani felépitése és fejlödéstörténete. - In: SzAKÁLL, S. and Weiszburg, T. (eds): A Telkibányai terület érces ásványai. Top. Miner. Hung. II, Herman Ottó Múzeum, Miskolc, pp. 45-81.

Kunwa, M. (2005): New localities of rare and interesting lichens in Gdańskie Pomerania. Part I. Acta Bot. Cassub. 5: 95-111.

KuKWA, M. and ZduńczyK, A. (2011): New localities of rare and interesting lichens from the Pomorze Gdañskie region and adjacent areas. - Acta Bot. Cassub. 7-9: 59-73.

Lambinon, J. (1966): Révision des macrolichens de Belgique et des régions voisines. Etude taxonomique et phytogéographique. - Institut de Morphologie végétale et de Botanique systématique, Université de Liège, Liège, $594+106$ pp.

LAmbinon, J. and SÉrusiaux, E. (1985): Le genre Xanthoparmelia (Vain.) Hale (Lichens) en Belgique et dans les régions voisines. - Bull. Soc. Roy. Bot. Belg. 118: 205-211.

Liffa, A. (1953): Telkibánya környékének földtana és kőzettana. - A Magyar Állami Földtani Intézet Évkönyve 41(3): 1-78.

LišKa, J., PAlice, Z. and Slavíková, Š. (2008): Checklist and red list of lichens of the Czech Republic. - Preslia 80: 151-182.

LöKös, L. and FARKAS, E. (2009): Revised checklist of the Hungarian lichen-forming and lichenicolous fungi. (Magyarországi zuzmók és zuzmólakó mikrogombák revideált fajlistája). - http:// www.nhmus.hu/modules.php?name=Tar-Noveny\&op= mozuzmolista 2

Magnin, A. (1906): Quelques lichens intéressants ou nouveaux pour le Jura. - Arch. flore jurass. 62: 9-21.

Matus, G., Lökös, L., Saraiva, L., Budai, J. and Antal, K. (2015): Talajlakó védett Xanthoparmelia fajok (Parmeliaceae) előfordulása a Dél-Nyírségben. - Bot. Közlem. 102(1-2): 155-156.

Molnár, K., Lökös, L., Schrett-Major, A. and FArkas, E. (2012): Molecular genetic analysis of Xanthoparmelia pulvinaris (Ascomycota, Lecanorales, Parmeliaceae). - Acta Bot. Hung. 54(1-2): 125-130. https://doi.org/10.1556/abot.54.2012.1-2.14

Motiejūnaité, J. (2002): Additions to the Lithuanian flora of foliose and fruticose lichens. - Bot. Lithuan. 8(1): 69-76.

Müller, J. (1949): Parmelia mougeotii Schaer. v ceskoslovenskem Slezsku. - Prirod. Sborn. [Ostrave] 10(4): 361-363.

Niklfeld, H. (1971): Bericht über die Kartierung der Flora Mitteleuropa. - Taxon 20(4): 545-571. https://doi.org/10.2307/1218258

Orange, A., James, P. W. and White, F. J. (2010): Microchemical methods for the identification of lichens. 2nd ed. - British Lichen Society; London, 101 pp.

Orthová, V. (2003): Confirmation of the occurrence of the lichen Xanthoparmelia mougeotii at the mountains Malá Fátra. - Acta Rer. Natur. Mus. Slov. 49: 18-26.

OrthovÁ-SlezÁ KovÁ, V. (2004): The genus Xanthoparmelia, nom. cons. prop. (lichenized Ascomycota) in Slovakia. - Mycotaxon 90(2): 367-386.

PIšút, I. (1993): List of extinct, missing and threatened lichens in Slovakia - the second draft. Biológia [Bratislava] 48(1): 19-26.

Pišút, I., LAC KovičovÁ, A. and LisickÁ, E. (1993): Súpis lisajníkov Slovenska. (Checklist of Slovak lichens). - Biológia [Bratislava] 48(Suppl. 1): 53-98.

Pišút, I., Guttová, A., LAC kovičová, A. and LisickÁ, E. (1998): Lichenizované buby (lišajníky). Lichen-forming fungi (lichens). - In: MARHOLD, K. and HINDÁK, F. (eds): Checklist of nonvascular and vascular plants of Slovakia. Veda, Bratislava, pp. 230-295. 
Pišút, I., Guttová, A., LACKovičová, A. and Lisické, E. (2001): Cerveny zoznam lisajníkov Slovenska (December 2001). (Red list of lichens of Slovakia (December 2001)). - Ochrana Prírody, Suppl. 20: 23-30.

Piterāns, A. (1996): Lichens. - In: Andrušaitis, G. (ed.): Red data book of Latvia 1. Fungi and lichens, Riga, pp. 117-191.

RANDlane, T. and SAAG, A. (eds) (1999): Second checklist of lichenized, lichenicolous and allied fungi of Estonia. - Folia Cryptog. Eston. 35: 1-132.

Randlane, T., Jüriado, I., Suija, A., Lônmus, P. and Leppik, E. (2008): Lichens in the new Red List of Estonia. - Folia Cryptog. Eston. 44: 113-120.

Richthofen, F. (1861): Studie aus dem ungarisch-siebenbürgischen Trachytgebirgen. - Jahrb. $d$. k.k. Geol. Reichsanst. 11(2): 153-278.

Reve, T. (1981): Parmelia mougeotii (steingardslav) i Norge, spesielt om forekomsten på Jæren. Blyttia 39: 121-124.

Santesson, R., Moberg, R., Nordin, A., Tønsberg, T. and Vitikainen, O. (2004): Lichenforming and lichenicolous fungi of Fennoscandia. - Museum of Evolution, Uppsala University, Uppsala, 359 pp.

Savić, S. and Tibell, L. (2006): Checklist of the lichens of Serbia. - Mycol. Balcan. 3: 187-215.

Smith, C. W., Aptroot, A., Coppins, B. J., Fletcher, A., Gilbert, O. L., James, P. W. and Wolseley, P. A. (eds) (2009): The lichens of Great Britain and Ireland. - British Lichen Society, London, $1046 \mathrm{pp}$.

Søchting, U. and Alstrup, V. (2008): Danish lichen checklist, Version 2. - Botanical Institute, University of Copenhagen, Copenhagen, $46 \mathrm{pp}$.

Stenroos, S., Velmala, S., Pykälä, J. and Ahti, T. (eds) (2016): Lichens of Finland. - Norrlinia 30: $1-896$.

Stordeur, R., Cezanne, R., Eichler, M., Heinrich, D., Kison, H.-U., Schiefelbein, U., Schönbrodt, M., Seelemann, A., Sipman, H. J. M., Thiemann, R. and Ungethüm, K. (2015): First records and noteworthy lichens and lichenicolous fungi from Saxony-Anhalt and the Western Part of the Harz National Park (Lower Saxony). - Herzogia 28(2): 654-678. https://doi.org/10.13158/heia.28.2.2015.654

Suppan, U., Prügger, J. and MAYrhofer, H. (2000): Catalogue of the lichenized and lichenicolous fungi of Slovenia. - Bibl. Lichenol. 76: 1-215.

SuZA, J. (1934): Lišejníky okolí Strečna nad Váhom (Malá Fatra na Slovensku). - Sborn. Muz. Slov. Spoločn. 27-28: 235-242.

SUZA, J. (1949): Dalsi prispevky k povaze oceanskeho elementu v lisejnikove flore stredni Evropy. Parmelia mougeotii a Buellia canescens. (Recherches supplementaires sur l'element oceanique dans le flore des lichens de l'Europe Centrale. Parmelia mougeotii et Buellia canescens). - Vestnik Kral. Cesk. Spol. Nauk. Tr. Mat.-prirod. 12: 1-30.

SZÁDECZKY, Gy. (1887): A magyarországi Obsidianok, különös tekintettel geológiai viszonyaikra. (Obsidians of Hungary with especial regard to their geological relationships). - Ért. Term. Tud. köréboól 16: 1-62.

SZÉKYNÉ Fux, V. (1970): Telkibánya ércesedése és kárpáti kapcsolatai. - Akadémiai Kiadó, Budapest, $266 \mathrm{pp}$.

SzepeSI, J. (2009): Geology of the rhyolite-perlite extrusions along Ósva Valley, Telkibánya. - $A$ Miskolci Egyetem közleményei, A sorozat Bányászat (Publications of the University of Miskolc, Geosciences, Series A, Mining) 78: 171-193.

SZepesi, J. and KozÁk, M. (2008): Palaeovolcanic reconstruction of the Cser Hill-Ó-Gönc rhyolitic range, Telkibánya, NW Tokaj Mts. - Földt. Közl. 138(1): 61-83. 
Szepesi, J., Harangi, Sz., Lukács, R. and Pál-Molnár, E. (2016): Facies analysis of a Late Miocene lava dome field in the Tokaj Mts. (Carpathian-Pannonian Region): implication for a silicic caldera structure? - In: BranCA, S., Groppelli, G., Lucchi, F. and Sulpizio, R. (eds): Abstract book. Geological fieldwork in volcanic areas: mapping techniques and applications III. Workshop on Volcano Geology, July 3-10, 2016, Sicily, Italy, pp. 60-63.

Thiers, B. (2016): Index Herbariorum: A global directory of public herbaria and associated staff. New York Botanical Garden's Virtual Herbarium. http://sweetgum.nybg.org/ih/

Trass, H. (1958): Kolmest Parmelia-liigist Eestis. (On three species of the genus Parmelia in Estonia). - Floristilised Markmed (Loodusuurijate Selts Eesti NSV Teaduste Akad. Juures) 1(1): $25-27$.

TÜrK, R. and HAfELlner, J. (2010): Nachtrag zur Bibliographie der Flechten in Österreich. - Biosystematics and Ecology Series No. 27, Verlag der Österreichischen Akademie der Wissenschaften, Wien, $381 \mathrm{pp}$.

VAN DEN Broeck, D., Spier, L. and Ertz, D. (2008): Verslag van de internationale korstmossendriedaagse in en rond het Zoniënwoud, 1-3 juni 2007. - Muscillanea 27: 25-37.

Verseghy, K. (1994): Magyarország zuzmóflórájának kézikönyve. - Magyar Természettudományi Múzeum, Budapest, $415 \mathrm{pp}$.

Wirth, V. (2001): Zeigerwerte von Flechten. - Scripta Geobot. 18(3): 221-243.

WirTH, V. (2010): Ökologische Zeigerwerte von Flechten - erweiterte und aktualisierte Fassung. - Herzogia 23: 229-248. https://doi.org/10.13158/heia.23.2.2010.229

Wirth, V., Hauck, M. and Schultz, M. (2013): Die Flechten Deutschlands. - Ulmer, Stuttgart, $1244 \mathrm{pp}$.

Wirth, V., Hauck, M., von Brackel, W., Cezanne, R., De Bruyn, U., Dürhammer, O., Eichler, M., Gnüchtel, A., John, V., Litterski, B., Otte, V., Schiefelbein, U., Scholz, P., Schultz, M., Stordeur, R., Feuerer, T. and Heinrich, D. (2011): Rote Liste und Artenverzeichnis der Flechten und flechtenbewohnenden Pilze Deutschlands. In: Ludwig, G. and Matzke-Hajek, G. (eds): Rote Liste gefährdeter Tiere, Pflanzen und Pilze Deutschlands. Band 6: Pilze (Teil 2). Flechten und Myxomyzeten. Landwirtschaftsverlag Münster. - Naturschutz und Biologische Vielfalt 70(6): 7-122.

(submitted: 20.03.2017, accepted: 11.05.2017) 